\title{
Management of Waqf Assets in Malaysia
}

\author{
Zunaidah Ab Hasan ${ }^{1 *}$ \\ Azhana Othman ${ }^{1}$ \\ Khalilah Ibrahim ${ }^{1}$ \\ Mohd Ab Malek Md Shah ${ }^{1}$ \\ Abd. Halim Mohd Noor ${ }^{1}$ \\ 1Zakat Research Institute of Malaysia (IKaZ), Universiti Teknologi MARA, Melaka, Malaysia \\ *Corresponding Author, Email: Zunaidah_hasan@gmail.com
}

\begin{abstract}
Waqf is one of the main mechanism in providing support for the development to all levels of the ummah more so for the underprivileged. Waqf institutions in Malaysia are under the jurisdiction of the 14 states rather than the Federal government. This paper reviews the development of waqf in Melaka, one of the states in Malaysia. It discusses a brief historical background, function and legal aspects of waqf matters. A brief information on the structure and administration of waqf in Melaka, Baitulmal is responsible for the sake of administering and managing such waqf assets in Melaka is also presented. This study is also concerned with examining of the current situation of development waqf asset; which is known as waqf sahamin Melaka through the record by Majlis Agama Islam Melaka (MAIM). Yet, it is undeniably true that some challenges and impediments pertaining to the issues of developing waqf assets; inter alia, lack of fund and expertise, poor documentation and the record value of waqf property and others.
\end{abstract}

Keywords: baitulmal; Majlis Agama Islam Melaka (MAIM); waqf assets; waqf saham

\section{A. INTRODUCTION}

Waqf plays a pertinent role as an Islamic public finance instrument that has a great potential mechanism to play as a significant role in generating a prominent source of financing for the state and for the needs of the Muslim ummah who are complex and growing. Although waqf had been implemented in Malaysia for many years, it has yet give impact in contributing welfare of the people in this present day.

Recognizing the potential and role in the economic development of the waqf, Malaysian Government has established JAWHAR in 2004 to strengthen governance endowments across the country, while Yayasan Waqf Malaysia (YWM) established in 2008 acting as the lead agency in developing the waqf property. Both of these agencies have undertaken various initiatives including activities research, publication, coordination and development of waqf properties in throughout the country. At the state level, the development of waqf property Islamic Religious Council (Majlis Agama Islam Negeri-MAIN) implemented by (or in collaboration with other agencies) as a shareholder sole trustee. These three 
agencies above cooperating closely in develop waqf in Malaysia.

There are 14 State Islamic Religious Councils in this country with each aimed of making the administration of Waqf is systematic and effective for the benefit of ummah. Each institution is given power to manage Waqf properties with the best standard of practice and contemporary management system to project the excellence of Islam (Z. Hasan and Abdullah, M. 2008).

Despite that, there are cases where waqf properties cannot be developed due to several reasons, which cannot be avoided. This issue needs to be addressed to safeguard the viability of waqf as income generators. This paper intends to discuss further the management of waqf in Malaysia focusing on waqf assets and in specifically in Melaka under the authorized of Majlis Agama Islam Melaka (MAIM).

\section{Background of waqf unit of MAIM}

MAIM was established on 28 September 1960, where it's main responsible in assisting and consulting Seri Paduka Baginda Yang di-Pertuan Agong in any Islamic religious matters. Chief Minister that responsible of Chairman of MAIM. MAIM the main unit to all agencies and Islamic institutions in Malacca. MAIM responsible to administrative and management of property of waqf in Malacca, that formal al-Mutawalli subject to Enactment Administrative of Islam State of Malacca 2002, Section 77 and Enactment Evidence Syariah law State of Malacca 2005, Section 32. (Zulkifli Hasan and Abdullah 2008), Rani, et al. 2014).

Figure 1

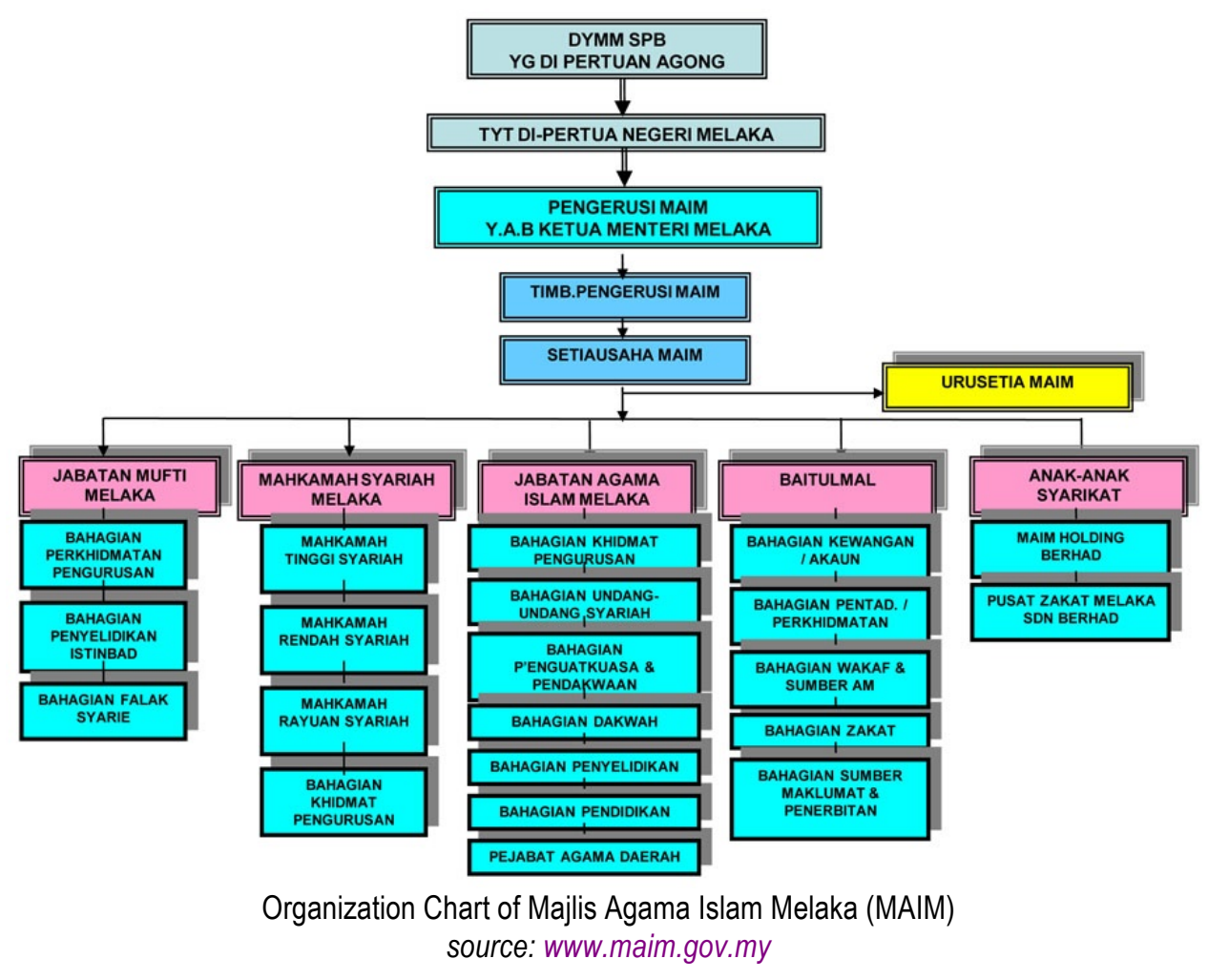




\section{Baitulmal}

Baitulmal manages all financial resources and property of the Muslim community. Primary responsibility of MAIM is managing the treasury and financial assets that are owned and entrusted to the Majlis Agama Islam Melaka as zakat, waqf and other sources allowed by the legislation in an effort to help the Muslims for the sake of socio-economic development and poverty eradication.

There are five main function of Baitulmal in Melaka, there is to increasing collection of zakat, implementing systematic distribution of zakat, developing waqfland, implementing the consecration of land and managing general resources.

Figure 2:

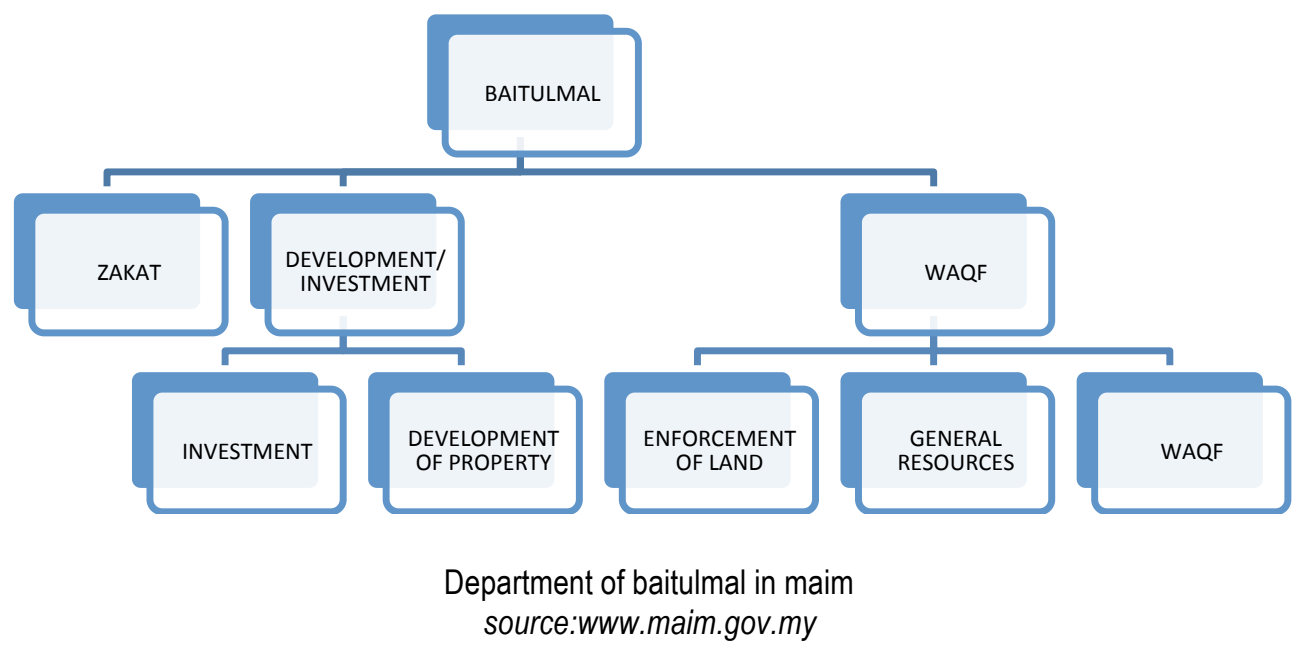

Islamic Religious Councils (SRIC) are the soul trustees of the waqf property or al- mutawalli and law on waqf, State of Malacca are provided under Enactment of Waqf 2005 (Zulkifli Hasan and Abdullah 2008). Department of Waqf in SRIC under of Baitulmal divided of 3 units that included Unit of Enforcement of Land, Unit of General Source and Unit of Waqf. There are 8 staff in unit of waqf, 2015, which covered for 3 district in Malacca.

\section{B. METHODS}

This paper uses the data related from Majlis Agama Islam Melaka (MAIN). This paper reviews the development of waqf in Melaka. It discusses a brief historical background, function and legal aspects of waqf matters.

\section{RESULT AND DISCUSSION}

\section{Definition of Waqf Assets}

Generally, waqf is a voluntary act of charity that comes under the general terms of sadaqah and infaq. Waqf is "an Arabic word meaning assets that are donated, bequeathed, or purchased for the purpose 
of being held in perpetual trust as ongoing charity (sadaqah jariya) or for a general or specific cause that Islam regards as socially beneficial" (Awqaf,2010). Waqf is the form of 'ibadah' to near oneself to Allah SWT by bequeathing property for the benefit of the public, especially the Muslims. (Kamri, 2010). (Kahf, 2004) defined waqf, from Shariah point of view as holding an asset and preventing its consumption for the purpose of repeatedly extracting its usufruct for the benefit of an objective representing righteousness/philanthropy. While,waqf is defined as an operation that combines the act of saving with the act of investment together from the economic definition.

\section{Categories of Waqf Assets}

Generally, there are two type of waqf that are: (i) bequests and (ii) charitable gift annuity/cash waqf. Thus, waqf assets can also be classified into fixed assets and movable assets. Both are likely to generate benefits for the public and donate towards wealth and prosperity (Abul Hasan \& Mohammad, 2010).

Fixed assets are permanent in nature, for example real estate or properties; come under the category of security of the act of 'continuous charity', which is one of the main characteristics of waqf (Kahf 1998).While, cash waqf had two forms. Firstly, cash was made into waqf to be used for free lending to the beneficiaries and secondly, cash was invested and its net return is assigned to the beneficiaries of the waqf.

\section{Analysis of Waqf Asset in Melaka}

MAIM, identified type of waqf to 3 categories, that Waqf Am, Waqf Khas and Waqf Saham. Type of waqf property, MAIM defined to 5 categories that are Waqf Al-Iqar (Immovable Property example of assets; mosques, building, school and etc), Waqf Al-Manqul ( Movable property mosques equipment such as: prayer mats and others), Waqf Al-Musya (Types of property that shared with others but can't be divided, example of two owner of the car, and only one of these owner dedicated to waqf a car), Waqf Al-Irtifaq ( the part of property example only one level of building from the part of other level are waqf to the public) and Waqf Al-Irsad ( property from part of government develop for public purposes, example type of land for school construction).

\section{a. Analysis of Waqf Saham (2005-2014)}

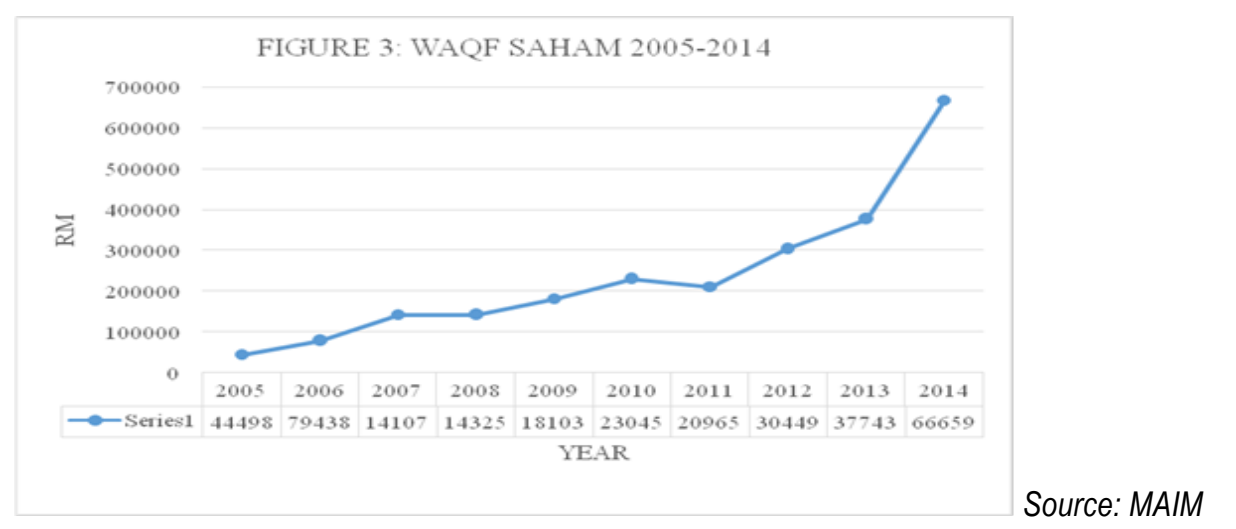


Mohsin, 2013) the collection of this kind of funds is meant to finance lawful goods and services needed in the different societies, must be invested first and only then its generated revenue to be given to beneficiaries. The term used by MAIM is waqf saham instead of cash waqf. From Figure 3shows total of collection for last ten years in Melaka RM 2,000,492.70. Starting of collection in year 2005 from RM44,498.03 and kept increasing year by year. The record showed in 2011 reducing 9\% from the previous year 2010. But from to 2013 to 2014 that increasing of total collection its $76.61 \%$ to RM 666,592.70. Waqf saham in Melaka that collected from 3 district, Melaka Tengah, Alor Gajah and Jasin. Collection from rent of Kompleks Al-Ehsan and Kiosk Apartment Pulau Melaka, are categorized in Waqf Saham.

\section{b. Analysis of Waqf Land in Melaka: Record of The Recent Data}

As a sole trustee, Majlis Agama Islam Melaka (MAIM) is the body which is responsible for the administration and management of waqf. Notwithstanding anything which contained in any instrument or declaration that creates, controls or administers of a waqf, MAIM shall be the sole trustee of either Waqf Am or Waqf Khas, Nazar Am and similarly situated inside and outside the State Melaka. The enacted sources of legislation are the State Administration of Religious Melaka 2002 section 77 and Syariah Court Evidence of Malacca in 2005 by virtue of Section 32.

Table 1: Statistic Of Waqf Am According District In Melaka

\begin{tabular}{|l|l|c|}
\hline \multicolumn{1}{|c|}{ NO. } & \multicolumn{1}{|c|}{ DISTRICT } & TOTAL \\
\hline 1. & $\begin{array}{l}\text { MELAKA } \\
\text { TENGAH }\end{array}$ & 314 \\
\hline 2. & ALOR GAJAH & 199 \\
\hline 3. & JASIN & 224 \\
\hline 4. & OTHERS & 2 \\
\hline \multicolumn{2}{|c|}{ TOTAL AMOUNT } & $\mathbf{7 3 9}$ \\
\hline
\end{tabular}

By referring to the Table 1above, it shows the statistic of Waqf Am based on the district in Melaka recently. The table shows that the total amount of waqf land is 739 lot whereby the district of Melaka Tengah is 314 lot, Jasin (224 lot), Alor Gajah (199 lot) and others (2 lot).

Table 2: Statistic Of Waqf Am In Melaka: Updated Until February 2015

\begin{tabular}{|l|l|c|c|}
\hline NO. & LAND USE & AREA & $\begin{array}{c}\text { NUMBER OF LAND } \\
\text { PARCEL }\end{array}$ \\
\hline 1. & CEMETERY & 165 & $213,922.3$ \\
\hline 2. & SCHOOL & 113 & $200,608.5$ \\
\hline 3. & MOSQUE & 170 & $195,531.25$ \\
\hline 4. & SURAU & 151 & $76,097.2$ \\
\hline 5. & WAQF AM & 140 & 195,919 \\
\hline & TOTAL & $\mathbf{7 3 9}$ & $\mathbf{8 8 2 , 0 7 8 . 2 5}$ \\
\hline
\end{tabular}

Source: MAIM 
On the other hand, with reference to Table 2, which shows the Statistic of Waqf Am according to The Lot In Melaka, the use of waqf land are as follow; mosque (170 lot), cemetery/ graveyard (165 lot), surau (151 lot), Waqf Am (140 lot) and school (113 lot) respectively. The total amount of the land use is 739 lot which covers $882,078.25$ acres.

\section{c. Development of Waqf Assets in Melaka}

Table 3: Statistics On Types Of Tenancy (Updated Until 2015)

\begin{tabular}{|c|c|c|c|c|c|c|c|c|c|c|}
\hline \multirow[t]{3}{*}{ District } & \multicolumn{9}{|c|}{ Types of Tenancy } & \multirow[t]{3}{*}{ Total } \\
\hline & \multicolumn{3}{|c|}{ Building / House /Premis } & \multicolumn{3}{|c|}{ Land } & \multicolumn{3}{|l|}{ Office } & \\
\hline & Tenancy & Vacant & Total & Tenancy & Vacant & Total & $\begin{array}{c}\text { Tenan } \\
\text { cy }\end{array}$ & $\begin{array}{c}\mathrm{Va} \\
\text { can } \\
\mathrm{t}\end{array}$ & Total & \\
\hline Melaka & 61 & 6 & 67 & 25 & - & 25 & 5 & - & 5 & 97 \\
\hline Tengah & & & & & & & & & & \\
\hline Alor & - & 1 & 1 & 3 & - & 3 & - & - & - & 4 \\
\hline Gajah & & & & & & & & & & \\
\hline Jasin & 2 & - & 2 & 4 & - & 4 & - & - & - & 6 \\
\hline Total & 63 & 7 & 70 & 32 & - & 32 & 5 & - & 5 & 107 \\
\hline
\end{tabular}

land 97 types of development and leasing implemented are like building / premises / home (61), while the land leased for car parking and similarly is 25 and an office building is leased for 5 pieces. The significant differences between in Alor Gajah and Jasin are 6 and 4 rentals of type category respectively which has resulted the overall number of development and leasing land in Melaka only 107 have been developed and implemented.

Table 4: Examples Of Types Of Development Which Have Fully Operated In Melaka

\begin{tabular}{|c|c|c|c|}
\hline NO & TYPES OF DEVELOPMENT & $\begin{array}{c}\text { DATE OF } \\
\text { CONSTRUCTION }\end{array}$ & REMARKS \\
\hline 1. & HOTEL PANTAI PUTERI & $\begin{array}{l}15 \text { JAN 2009- } 14 \text { SEPT } \\
2011 \text { (COMPLETED) }\end{array}$ & $\begin{array}{l}\text { Under RMK-9, Cooperation } \\
\text { between JAHWAR \& MAIM, } 8 \\
\text { floors, } 87 \text { rooms, } 3 \text { star - } \\
\text { rating, } 1 \text { seminar room and } \\
\text { has been officiated on } 11 \text { Nov } \\
2011 \text {. }\end{array}$ \\
\hline 2. & HOTEL PRIMA & $\begin{array}{ll}2011- & 2014 \\
\text { (COMPLETED) }\end{array}$ & $\begin{array}{l}\text { Developed under privatisation } \\
\text { project based on the concept } \\
\text { of mortgage for } 30 \text { years, } \\
\text { monthly tenancy of building for } \\
\text { RM } 15000 \text { sebulan \& } \\
\text { maintained for each } 5 \text { years, } \\
82 \text { rooms and seminar rooms. }\end{array}$ \\
\hline 3. & $\begin{array}{l}\text { BAZAR RAKYAT } \\
\text { MELAKA }\end{array}$ & $\begin{array}{l}\text { MEI } 2010 \text { - DIS } 2010 \\
\text { (COMPLETED) }\end{array}$ & $\begin{array}{l}\text { Constructed on a portion of } \\
\text { Lot } 1870 \text {, Pulau Besar, Mukim } \\
\text { Pernu, Melaka Tengah District } \\
\text { and has been officiated on } 12 \\
\text { March } 2011.4 \text { units of bazar } \\
\text { rakyat, tenancy of RM150 x } 4 \\
\text { units per month. }\end{array}$ \\
\hline 4. & $\begin{array}{l}\text { BAZAR RAKYAT MAIM TANJUNG } \\
\text { MINYAK }\end{array}$ & $\begin{array}{l}9 \text { JAN } 2010 \text { - } 19 \text { JULAI } \\
2010\end{array}$ & $\begin{array}{l}\text { Constructed on Lot } 1491 \text { with } \\
\text { the cost of RM80,000.00, } 2\end{array}$ \\
\hline
\end{tabular}




\begin{tabular}{|c|c|c|c|}
\hline & & & $\begin{array}{l}\text { units, RM100 × } 2 \text { units per } \\
\text { month. }\end{array}$ \\
\hline 5. & $\begin{array}{llll}\text { RUMAH PANGSA } & \text { AL } & \text { EHSAN } \\
\text { TENGKERA } & & & \end{array}$ & - & $\begin{array}{l}\text { Location : Tengkera, owned } \\
\text { by MAIM, }\end{array}$ \\
\hline 6. & $\begin{array}{l}\text { DEVELOPMENTPROJECT KASEH } \\
\text { JASIN }\end{array}$ & 4 JULY 2012 & $97 \%$ almost completed \\
\hline 7. & $\begin{array}{lrl}\text { PLANNED } & \text { CONSTRUCTION } & \text { OF } \\
\text { MAAHAD TELOK MAS SCHOOL } & \\
\end{array}$ & 15 OCT 2012 & $67 \%$ almost completed \\
\hline 8. & $\begin{array}{l}\text { MAINTENANCE WORK AT MASJID } \\
\text { KG. HULU KG. KLING }\end{array}$ & - & $\begin{array}{l}\text { Both of the mosques have } \\
\text { been gazetted as 'Mosque of } \\
\text { Heritage' under the } \\
\text { maintenance of Jabatan } \\
\text { Warisan Negara. }\end{array}$ \\
\hline 9. & $\begin{array}{l}\text { RUMAH FAKIR MISKIN KG. PADANG } \\
\text { JAMBU, MELAKA TENGAH }\end{array}$ & - & $\begin{array}{l}\text { For the placement of the poor } \\
\text { which consists of } 26 \text { houses } \\
\text { unit. }\end{array}$ \\
\hline 10. & $\begin{array}{l}\text { RUMAH FAKIR MISKIN PANTAI } \\
\text { PERINGGIT, MELAKA TENGAH }\end{array}$ & - & 24 units \\
\hline 11. & $\begin{array}{l}\text { RUMAH FAKIR MISKIN } \\
\text { MURAI JAYAN DURIAN TUNGGAL }\end{array}$ & - & 31 units \\
\hline 12. & $\begin{array}{l}\text { REPAIRS AND MAINTENANCEWORK } \\
\text { AT RUMAH PANGSA AL IHSAN } \\
\text { TENGKERA }\end{array}$ & $\begin{array}{l}18 \text { DEC } 2012 \text { - } 28 \text { FEB } \\
2013\end{array}$ & $75 \%$ completed \\
\hline
\end{tabular}

Source: MAIM

Referring to Table 4 above, it can be concluded that the above examples of the types of development that has been implemented and fully operated in Malacca. There are many other projects in the pipeline and is still in the process of discussion at the level of MAIM. Thus, it is the roles of MAIM to identify the potentiality of waqf land for such development for the well - being economic development of ummah. Every development undertaken is for the well - being ummah; regardless whether it is profitable or in terms of social development community. Referring to the following passage from the 9th Malaysian Plan:

"Waqf land and properties under the state religious Islamic authorities will be developed to tap their productive potential as well as to spawn new entrepreneurs. And development of commercial assets such as hotel and business premises on waqf land will be expanded to increase Bumiputera ownership of non-financial assets. A strategic plan will be drawn up to ensure that the income generated from the development of waqf land will enable state religious authorities to be more selfreliant in developing new waqf land.

\section{Issues and challenges of waqf assets in Melaka: a brief analysis}

Significantly, it is undeniably true that waqf is a unique concept of Islamic product economically. Being as a tool to strive towards a well-being society collectively, there is a need for a good governance and administration in order to avoid from any tribulations efficiently. Yet, the existence of conflict of jurisdiction between syariah and conventional system still on-going which has resulted the ambiguity and impediment towards it smooth running of waqf system in Malaysia. 
Yet, in certain occasions, with reference to the issues of assets management, some of the lands are abandoned and not fully administered properly. In fact; as waqf is apart of the platform in ensuring the well - being of Muslim ummah economically, it is undeniably true that the sense of empowering of this entity is a necessity as it is solemnly emphasized based on the religious concept of maqasid syariah (objectives of syariah) holistically. Thus, there shall be no issues pertaining to the lack of productivity of waqf assets as a whole.

Furthermore, it can be observed that another obstacles faced by MAIM is relating to the poor management of waqf assets from the aspect of documentation. This is due to the fact that the storage of the relevant data is still remained by using a conventional system manually.

Meanwhile, pertaining to the issue of status of land, it can be said that basically, any costs or expenses which are related to transfer of title is sustained by MAIM. It also covers the payment of quit rent, costs of maintenance and others which eventually will create such a burdensome on the part of MAIM to make sure that such lands are owned legally by them. Thus, legal ownership is vitally significant for MAIM in order to ensure that such waqfland can be developed for the wellbeing of ummah accordingly. In fact, it is clear that this religious concept need such a great recognition in order to enforce the validity and legal enforcement.

Significantly, there should be a proactive move to be initiated by the relevant authorities for the betterment of the good governance of waqf land accordingly. Being as a tool to strive towards a wellbeing society collectively, there is a need for a good governance and administration in order to avoid from any tribulations efficiently.

\section{CONCLUSIONS}

Waqf institution is indeed recognised as apart of the mechanism of eradicating poverty; as well as generating the development of Muslim ummah from the economic dimension. Indeed, time goes on, there is a need for the betterment of good governance of waqf matters accordingly. In relation to this, such strategic strategies and actions must be implemented by MAIM in order to make sure that the management and administration of waqf matters in Melaka would run smoothly; within the ambit of Islamic princles of maqasid syariyyah holistically. 


\section{References}

Hasan, Z., and N. Abdullah, M. 2008. "The Investment of Waqf Land As An Instrument of Muslims',." In Economic Development In Malaysia, Dubai International Conference on Endowments',Investment, 4-6 February 2008; United Arab Emirates.

Hasan, Zulkifli, and Muhammad Najib Abdullah. 2008. "The Investment of Waqf Land as an Instrument of Muslims' Economic Development in Malaysia." In Dubai International Conference on Endowment' Investment, 4-6th February 2008 Organized by Awqaf and Minors Affairs Foundation, Dubai, the United Arab Emirates.

Kahf, M. 1998. "Financing Development of Awqaf Property,." In Seminar on Development of Awqaf, Organized by IRTI,Kuala Lumpur,Malaysia,March,2-4,1998.

— 2004. "Shari'ah and Historical Aspects of Zakah and Awqaf. Backgr." In Ound Paper Prepared for Islamic Research and Training Institute. Islamic Development Bank.

Kamri, Nor 'Azzah. 2010. "The Roles of Ethics in Waqf Management: Case of JAWHAR." Shariah Journal 18 (3).

Mohsin, Magda Ismail Abdel. 2013. "Financing through Cash-Waqf: A Revitalization to Finance Different Needs." International Journal of Islamic and Middle Eastern Finance and Management 6 (4).

Rani, Mohd Affandi Mat, Baharuddin Sayin, Ahmad Zaki Abdul Latiff, Amal hayati Ishak, and Razali Othman. 2014. Transformasi Waqf Di Malaysia: Isu Dan Cabaran, Institut Kajian Zakat Malaysia(IKaZ). Universiti Teknologi MARA(UiTM). 
Management of Waqf Assets in Malaysia 